\title{
The Relationship between Financial Sector Development and Economic Growth in Nigeria: Cointegration with Structural Break Approach
}

\author{
Sunday Elijah, Namadina Hamza.
}

\begin{abstract}
This research investigates the relationships between the financial sector development and economic growth in Nigeria, using annual time series data for the period between 1981 to 2015. This research examines the long-run relationship between the financial sector development and the economic growth in Nigeria, and applies the Gregory and Hansen (1996a, b) cointegration approach with one endogenously determined structural break and the vector error correction model. This research finds out that, there exist cointegration among the financial development, trade openness and economic growth with structural break date in 2010 and the results from the vector error correction model finds there is significant and negative relationship between financial development and the economic growth in Nigeria in the study period. In addition, the findings of this study indicate that accounting for structural break in VECM improves the significance and thus reliability of the model applied. The estimated model is found to have passed diagnostic tests and is found to be stable. The paper recommends that to achieve the desired economic growth level financial development should be supported with other proactive measures such as sound institution and basic infrastructure to complement the effort of financial sector reforms. Moreover, future analysis should always consider the structural breaks while conducting macroeconomic empirical analysis as it helps in avoiding having spurious results
\end{abstract}

Keywords: Financial Development, Economic Growth, Structural Break.

JEL Classification: O43, Q33

\section{INTRODUCTION}

The financial sector development role on economic growth process has been debated for long. This could be traced, back to the works of (Schumpeter 1912) (McKinnon 1973). The roles of financial development on economic growth has long been considered by economists and researchers who examine the relationships that exist between financial development and the economic growth. Financial development do lead to economic growth by way of increasing the efficiency and effectiveness of financial institutions. Similarly it leads to innovations in the financial system and reduction in costs of operations (Muhammad 2011) (McKinnon 1973) (Levine 1997). Other scholars and researchers contend that it is economic growth that lead to

Revised Manuscript Received on April 19, 2019.

Sunday Elijah, Department of Economics, Faculty of Management \& Social Sciences, Federal University Gusau, Zamfara State, Nigeria,

Sunday Elijah, Department of Economics,Faculty of Economics and Management,Universiti Putra Malaysia, 43400 UPM Serdang, Selangor, Malaysia.

Namadina Hamza, Department of Economics, Faculty of Management \& Social Sciences,Federal University Gusau, Zamfara State, Nigeria. (Email:elijahsundayecons@gmail.com)

the financial development (Lucas Jr 1988) (Stern 1989). The relationship between financial development could either be positive, negative or no relationship between the two (Qamarzumman 2017, Zheng 2009, Naceur 2007).

The causality direction between the financial development and the economic growth show the findings are mixed and inconclusive. Some researchers observed and found the unilateral causality running from the financial sector to the economic growth supporting supply leading hypothesis (King 1993, Odeniran 2010, BALIAMOUNELUTZ 2013). Others found the unidirectional causality that is running from the financial development which is known as the demand-following hypothesis (Liang 2006) (Akinlo and Egbetunde 2010) (BALIAMOUNE-LUTZ 2013), while others observe and found existence of bidirectional causality between the financial development and the economic growth (Dabos and Gantman 2010, BALIAMOUNE-LUTZ 2013) (Calderón 2003). There are other studies that, did not found significant link(s) between the finance and the economic growth (Demetriades and Hussein 1996, BALIAMOUNELUTZ 2013).

There is therefore, the need to further reexamine the relationships between the financial development and the economic growth in Nigeria, accounting for the presence of structural break. The major shortcoming of other previous studies on Nigeria is that it failed to consider political, economic changes that occur in the country which could alter the relationship among macroeconomic variables. The rest of this paper is organized as follows: following this introduction is the theoretical framework and literature review. The third section is the data and methods, fourth section of the paper is result presentation and discussion of findings, the last section or aspect is conclusion and policy implications.

\section{LITERATURE REVIEW}

\section{Theoretical Framework and Literature Review}

The link between the financial development and the economic growth has attracted the intention of researchers in recent period. Financial development in this framework is viewed as a channel through which resources are channeled to the economy real sector by the changing the productivity and efficiency of capital. It also assists in accumulation of capital by way of savings mobilization and allocation of 
resources (Levine 1997). The finance-growth nexus can be traced, back to work of (Schumpeter 1912) that argues on the role of financial intermediaries as a channels of saving mobilization by managing risks, reduce transactions cost and enhance competitiveness which aids technological innovation and hence enhance economic growth. (Shaw 1973) (McKinnon 1973) argued that the financial liberalization help in increasing savings, which leads to capital accumulation that enhances economic growth. However, earlier economic growth theories such as (Rostow 1960) (Coser 1956) do not consider the role of the financial development as a factor of economic growth, but few ones such as Harrod and Domar emphasize the need to increase saving rate as a means of increasing the growth rate in the economy arguing that saving ratio and national output ration increase growth rate in the output.

Majd (2017) argued that there are hypothesis of relationships between the financial development and the economic growth. The first, is the finance-lead growth hypothesis also known as hypothesis of supply-leading, the argument of the hypothesis is that the existence of financial sector and its financial intermediation function of channeling resources from lenders to users of funds will provide efficient and effective resource allocation, thereby helping other sectors in their process of growth (BALIAMOUNE-LUTZ 2013) (Akinlo and Egbetunde 2010).

The second hypothesis is growth-finance lead hypothesis, or the demand following hypothesis, a hypothesis championed by Robinson (1952). The argument of this hypothesis is that, it is the growth that stimulates financial development. That growth in real sector of the economy lead to increase in the demand for the financial services and thus, the development, of the sector from increased demand of its services (Oluitan 2010).

The third view is the hypothesis of feedback or the existence of bidirectional causality. This hypothesis postulates that, there is mutual causal effect between finance and the economic growth. The hypothesis argues that a financial system that is well-developed can promote economic expansion, through technological service and product innovations (Schumpeter 1912). This will in-turn leads to an increased the financial services demand (Levine 1997). The response to, the increased demand for the financial services by the banking sector will stimulate further economic expansion in the real sector. Both the financial development and the economic growth, are interdependent, and that there could be bi directional causality among the two (Luntel 1999) (Kar 2000).

\section{EMPIRICAL LITERATURE REVIEW}

Qamarzumman (2017) investigate the effect of the financial development in Bangladesh with the use of annual data, for the time period of 1980 - 2016 applying the approach of autoregressive distributed lag bound testing, found positive significant long-run relationship between the financial development and the economic growth. Using financial time series datasets, Bara, Mugano et al. (2016) for the period between 1980 and 2013 applying bounds testing approach found that the financial development, had a positive significant effect, on the economic growth when ratio of broad to, narrow money is used, as a proxy of financial development. Similarly, Dilek (2016) estimate relationship between the financial development and the economic growth, in a panel, of 40 countries by the, use of Augmented Mean Group (AMG), and common correlated effect found positive significant effect of financial development on the economic growth. Zheng (2009) found that, there is a positive relationship, between the financial development and the economic growth, with the use of annual data of 29 provinces, for the period $1999-2005$. However, Samargandi (2013) examine Relationship between the financial development and the economic growth by the use of a panel, of 52 middle income countries and using panel data analysis method accounting for heterogeinity find a negative significant relationship between the financial development and the economic growth. Naceur (2007) indicate that the relationship, between the financial development, and growth is negative, after controlling for the stock market development in these selected 11 countries of MENA for period of $1979-2003$. Huang (2009) studies the effects of growth financial intermediary development, for a set of, 71 countries with distinct income level by the use of, instrumental threshold approach. Their finding showed a positive non-linear effect of finance on the economic growth, with impact on low income countries being greatly pronounced, than economies of high income.

Fang and Jiang (2014), investigate the effect of the financial development on the primary, the secondary and the tertiary industries, in china. They found that the financial development, has no effect on growth, of the primary industry but, has Jiang effect that is positive on growth of the secondary and tertiary industries. Fang and Jiang (2014), argued that banking sector, mainly making loans to the secondary and the tertiary industries, as the primary industry, had enjoyed, slow growth since the year 1998.

Odeniran (2010), Udeaja (2010) also investigated the relationships between the financial sector development and the economic growth in Nigeria, with the use of annual time series for the period $1960-2009$. The financial sector proxies used were: bank deposit liability to GDP, broad money to GDP, net domestic domestic credit to GDP and private sector credit to GDP. Evdence, from analysis of cointegration suggest that, a positive long-run relationship existing between the real output and the variables of financial sector which is in harmony with the finance-led theories. Kapingura (2013) examined dynamic relationships between the financial development and the growth in South Africa. The resulted suggested that financial intermediaries and the financial markets have different impacts on economic growth given their, different roles in the economy. In particular, there are bi-directional causality between the stock market and the economic growth was established. Balago (2014), studied the financial sector development and the economic growth in Nigeria. The results showed that the development in financial sector as measured by credit banking sector, total market capitalization and the foreign

Blue Eyes Intelligence Engineering

$\&$ Sciences Publication 
direct investment affect economic growth positively. This results, is consistent with the number of studies reviewed earlier in literatures, that found the financial sector to affect positively the real gross domestic product.

\section{METHODOLOGY}

\section{Source of Data}

The study employed annual data from 1981 to 2015 for its analysis. The data was obtained from the statistical bulletin of Central Bank of Nigeria (CBN) various editions. The chosen period was to enable the researcher to capture effect of the financial development on the economic growth in Nigeria considering the availability of data and looking at the current development challenges the country is facing coupled with financial sector development.

\section{Model Specification and Variables Measurement}

Following the works of Odeniran (2010) (Udeaja 2010) the model used to investigate the effects of the financial sector development on the economic growth in Nigeria, the following model is specified, in its functional form by

$\mathrm{GDP}=\mathrm{f}$ (financial development, trade openness)

\section{(1)}

and the model can be expressed in an econometric form as follows

$$
\ln G D P_{t}=\beta_{0}+\beta_{1} F D_{t}+\beta_{2} \text { openness }_{t}+\mu_{t}----(2)
$$$$
\text { Where; }
$$

ln GDP = the natural logarithm, of nominal gross domestic product, proxy of economic growth

$\mathrm{FD}=$ the measure of Financial development proxied by the ratio, of broad money supply (M2) to the Gross Domestic Product

Openness $=$ the ration of, the sum of exports and imports divided by the nominal gross domestic product, as a control variable.

$\beta_{0}=$ the intercept term

$\beta_{1}=$ the coefficient of stock market development and a priori is expected to have positive relationship with the dependent variable

$\beta_{2}=$ the coefficient of the exchange rate and it is expected, to have effect that is negative on the economic growth. And

$\mu_{t}=$ is the error term that is assume to be normally distributed, with zero mean, and constant variance.

\section{METHOD OF DATA ANALYSIS}

The first step in carrying out research using time series data is to investigates, the properties of stationarity of the variables so as to ascertain they do not contain unit root, in other words they are stationary. This study investaugates the staionarity property of, the variables using Augmented Dickey Fuller test of unit roots in addition to the Phillips (1988) unit roots test as it is considered to have more power size than Augmented Dickey and Fuller (1979) stationarity test.

The next step after determining, the order of integration, of variables in the model is that if, they are found to be cointegrated of order1 i.e I (1), (Gregory and Hansen 1996, Gregory and Hansen 1996) approach is used to, determine the long-run association ship among variables used in the study.

Following existence of the cointegration, among the variables as evidence by trace statistic and maximum Eigen values statistic as shown in Table, the model of vector error correction is estimated, to determine the long-run as well the short-run relationships between the variables as well as the speed, of adjustment, from the short-run relationship to the long run relationship represented by error correction term.

The next stage is to conduct the diagnostics checking to determine the model adequacy used in, the conduct of the study using the, cumulative sum of residuals and the cumulative sum of squares of recursive residuals (CUSUM) and other diagnostic tests.

\section{Gregory \& Hansen Approach of Cointegration}

The study uses (Gregory and Hansen 1996), residual based test for approach of cointegration for the presence of structural break at unknown date. This method of testing for cointegration is superior to Engle and Granger (1987) coitegration approach as the later tends, to under reject, the null hypothesis, of no cointegration even if there exist cointegration at unknown period in the sample data. The Gregory and Hansen (1996) approach of cointegration is the extension of the Engle and Granger (1987) cointegration and it involves testing the null hypothesis, of no cointegration against, the alternative hypothesis of cointegration, with structural breaks at unknown date based on the extension of $\mathrm{ADF}, \mathrm{Z} \alpha$ and $\mathrm{Zt}$ Tests.

The Engle and Granger (1987) approach to cointegration approach assuming existence of three independent variables is given by the equation as:

$$
y_{t}=\beta+\alpha_{1} x_{t}+\alpha_{2} m_{t}+\alpha_{3} n_{t}+\varepsilon_{t}
$$

Where Yt is the dependent variable and is $\mathrm{I}(1)$ and $\mathrm{x}_{\mathrm{t}}, \mathrm{m}_{\mathrm{t}}$ and $\mathrm{n}_{\mathrm{t}}$ are the independent variables and the coefficients $\alpha_{1}-\alpha_{3}$ are assumed to be constant, that is they do not change with time and $\varepsilon_{t}$ is assumed to be white noise. However, it could be possible that the cointegration may take time to manifest long-run relationship and the time of the long-run relationship may be unknown but can however be determined endogenously. The structural change may be reflected in the changes in the intercepts $(\beta)$ or changes in the slopes $\left(\alpha_{1}, \alpha_{2}, \alpha_{3}\right)$ or changes in the slopes and the trend.

Gregory and Hansen (1996) used an indicator variable defined as:

$\mathrm{Dt}=\{0$, if $t \leq[n \tau]\}$ and $\mathrm{Dt}=\{1$, if $t>[n \tau]\}$, where: the unknown paraters $\tau(0,1)$, denotes the relative timing, of the structural change and [ ] is an integral part. To test, for cointegration, in the presence of structural breaks. Gregory and Hansen (1996) proposed the use of four models to test the null-hypothesis, of no cointegration, against the alternative that there exist relationaship cointegrating among variables used in the study. The Models as used by the (Gregory and Hansen 1996) are as follows:

\section{Model 1:- Level Shift (C) Model}

This is a simple case model where the shift affects only the constant with the slope coefficients remaning the same 
after the shift and the parameter $\beta_{1}$ indicates the intercept, before the shift, and $\beta_{2}$ is, the intercept after the shift.

$$
y_{t}=\beta_{1}+D_{t} \beta_{2} \alpha_{1} x_{t}+\alpha_{2} m_{t}+\alpha_{3} n_{t}+\varepsilon_{t}
$$

\section{Model 2:- Level shift with trend (C/T) Model}

The level shift, with trend model of the Gregory and Hansen (1996) cointegration approach in, the presence of, one endogenously determined, structural break includes the trend to the level shift model and is given as:

$$
y_{t}=\beta_{1}+D_{t} \beta_{2}+\lambda t+\alpha_{1} x_{t}+\alpha_{2} m_{t}+\alpha_{3} n_{t}+\varepsilon_{t}
$$

Where the coefficient $\lambda$, represents the coefficient of the trend term $\mathrm{t}$

\section{Model 3: Model with Changes affecting the intercept and slope}

The third model of the Gregory \& Hansen cointegration approach to cointegration considers the shift affecting the intercepts as well as the slope coefficients and is given as:

$$
y_{t}=\beta_{1}+D_{t} \beta_{2}+\alpha_{1} D_{t} x_{t}+\alpha_{2} D_{t} m_{t}+\alpha_{3} D_{t} n_{t}+\varepsilon_{t}
$$

Where Dt is a dummy variable indicating the timing of the break

\section{Model 4: Regime Shift with Trend}

The fourth model of the cointegration test as given by Gregory and Hansen suggest the shift as affecting the slope coefficient, the trend as well as the slope coefficients of the model and is presents below as:

$y_{t}=\beta_{1}+D_{t} \beta_{2}+\lambda t+\alpha_{1} D_{t} x_{t}+\alpha_{2} D_{t} m_{t}+\alpha_{3} D_{t} n_{t}+\varepsilon_{t}$

Gregory and Hansen (1996), Gregory and Hansen (1996) propose three tests for the residuals of the series to

$$
\begin{aligned}
& A D F *={ }_{\tau \in T}^{\inf } A D F(\tau) \\
& Z \alpha={ }_{\tau \in T}^{\inf } Z \alpha(\tau) \\
& Z t={ }_{\tau \in T}^{i n f} Z t(\tau)
\end{aligned}
$$

As a result of the existence of cointegration, among the variables used in the model; Vector error correction model (VECM) is specified so as to determine the long-run, as well as short-run coitegrating coefficients of the model. Following the identification of structural break in, the model, the VECM is specified taking into account the structural break using a dummy variable is represented as follows following the works of MEDHIN and MEKONNEN (2019).

$$
\Delta X_{t}=\lambda+\delta X_{t-1}+\sum_{i=1}^{q-1} \Upsilon \Delta X_{t-i}+D \phi_{k, t}+\mu_{t}
$$

From equation $\lambda$ is a, vector of intercepts and $X$ is a vector, of endogenous variables included in, the model and $\phi$ is, a vector of dummy variables accounting for, the period of structural break, in the VECM MEDHIN and MEKONNEN (2019). $\delta$ is a a reduced rank matrix which can be separated into $\alpha$ and $\beta$. $\phi$ is a vector of dummy variable coefficients defined as:

$$
\begin{aligned}
& \phi_{k, t}=\left\{\begin{array}{l}
1 \text { for any period after break point } \\
0 \text { otherwie }
\end{array}\right. \\
& \mathrm{It}=\left\{\begin{array}{l}
1 \text { for a break period that is equal to brekpoint } \\
0, \text { otherwise }
\end{array}\right.
\end{aligned}
$$

Where $\phi$ is the break point dummy and I is an indicator variable. The indicator variable provides for the stability of, the vector error correction model when the break period is known apriori (Garba, Bello et al. 2016).

If series variables are, integrated of the same order, but non-cointegrated a vector autoregressive (VAR) model is specified in the form of first differenced values of the determine if there is cointegration.

integrated series to run Granger causality tests (Acaravci 2010). However, if there is at least one cointegrating vector, the residuals of the cointegrating equation should be estimated and the first lag value of te residuals added to the cointegrated equation in the form of vector error correcting equation (Acaravci 2010). The residuals from the cointegration equation are estimates and its one lag level is added to the model in the vector error correction model as an, error correction term, to equation (Johansen 1988) as follows:

$$
\begin{aligned}
\Delta \ln G D P=\beta_{0}+ & \sum \beta_{i} \Delta F D_{t-i}+\sum \beta_{i} \Delta \text { openness }_{t-i} \\
& +\sum Y_{i} \Delta \text { Dum }_{t-i}+\alpha_{i} \text { resid }_{t-i}+\mu_{t}-- \\
& -(2)
\end{aligned}
$$

The error correction that adjusts the short-run disequilibrium to the long-run relationship is, expected to be significant and negative with the absolute value of less than unity.

\section{RESULTS}

This section of the paper presents, the results, of the test

\begin{tabular}{|c|c|c|c|c|}
\hline & & & & \\
\hline & $\begin{array}{l}\text { Augmented } \\
\text { Fuller (ADF }\end{array}$ & Dickey & Phillips Perc & on (PP) \\
\hline $\begin{array}{l}\text { Variab } \\
\text { le }\end{array}$ & $\begin{array}{l}\text { Level } \\
\text { Constant } \\
\text { without } \\
\text { trend }\end{array}$ & $\begin{array}{l}\text { Constant } \\
\text { with trend }\end{array}$ & $\begin{array}{l}\text { Constant } \\
\text { without } \\
\text { trend }\end{array}$ & $\begin{array}{l}\text { Constant } \\
\text { with trend }\end{array}$ \\
\hline IGDP & $\begin{array}{l}-0.012386( \\
0)\end{array}$ & )$^{-1.91653(0}$ & $0.036139[3]$ & $-1.9902[1]$ \\
\hline $\begin{array}{l}\text { Fin. } \\
\text { Devt }\end{array}$ & $-2.0545(1)$ & $-2.4769(0)$ & $-2.07313[3]$ & $-2.5139[3]$ \\
\hline $\begin{array}{l}\text { Openne } \\
\text { ss }\end{array}$ & $-1.9985(0)$ & $-1.6263(0)$ & $-1.8411[2]$ & $-8.1815[0]$ \\
\hline & First & ence & & \\
\hline lGDP & $\begin{array}{l}-4.8767 * * \\
*(1)\end{array}$ & $\begin{array}{l}-4.7589 * *( \\
0)\end{array}$ & $\begin{array}{l}-4.7876 * * *[ \\
4]\end{array}$ & $\begin{array}{l}-4.6642^{* *} \\
*[4]\end{array}$ \\
\hline Fin. & $-5.3788 * *$ & $-5.2889 * *$ & $-5.8959 * * *[$ & $-5.7799 * *$ \\
\hline Devt & $*(0)$ & $*(1)$ & 11] & $*[3]$ \\
\hline Openes & $-4.8767^{* *}$ & $-8.1815^{* * *}$ & $-7.6153 * *[2$ & $-8.6064^{* *}$ \\
\hline & $*(0)$ & $*(0)$ & , & $*[2]$ \\
\hline
\end{tabular}
for stationarity of the, variables, and the interpretations, and it includes test for, unit root using, the Augmented Dickey and Fuller (1979) and Phillips (1988) test of Unit root.

The results, in the table indicates, that the results of Augmented Dickey and Fuller (1979) and Phillips (1988) have all indicated all the variables have, a unit root at their level value. However, the first difference of the series indicates that they become stationary after first difference.

Table 1: Augmented Dickey Fuller (ADG) and Philips Peron Test of Unit Roots Results.+ the use of data of time series.

Notes: $* * * \& * *$ denotes significance at, $1 \%$ and $\% \%$ level of significant respectively. The figures in the parenthesis denotes the optimal lag

Length selected, on the basis of Schwartz Information Criterion. The figures in brackets represent the Bandwidth used in the Phllips - Perron test Based on Newey West Bandwidth criterion.

Source: Computed by the author using E VIEWS 9.0 with the use of data from the statistical bulletin of Central 
Bank of Nigeria (2015).

The results for the test of the test of unit roots in Table 1 indicates that none of, the variables used in the model is stationary at its level value for all the two cases of constant only and constant with trend. However, the unit root test has shown that, all the variables, are stationary at first differences from both, the augmented Dickey Fuller, as well as the as well as the Phillips- Peron tests.

Unit Root test with Structural Break and Interpretation of Results

This subsection of the paper presents the result of the test for structural breaks. The test considers the possibility of having single structural breaks that is assumed to be endogenously determined. The result is presented in the Table3.

Table 2:- Test for Unit Root with Structural Breaks

\begin{tabular}{lllll}
\hline Variables & \multicolumn{2}{l}{ Level Values } & \multicolumn{2}{l}{ First Difference Values } \\
\hline & Break & Unit & Break & Unit Root \\
& Date & Root & Date & \\
lnGDP & $1992 * *$ & -3.9215 & 1998 & $-6.1855 * * *$ \\
Fin.Devt & $2001 * *$ & -3.4176 & $2011 * * *$ & $-6.8686 * *$ \\
Openness & $2010 * *$ & -4.5149 & $2011 *$ & $-9.4262 * * *$ \\
\hline
\end{tabular}

Notes: ******and $*$ denotes significance level at 1,5 and 10 per cent respectively.

Source: Computed by the Authors using E Views 9.0 using data obtained, from the statistical bulletin of Central Bank of Nigeria (2015).

The results of, the test of unit root, in the presence, of one structural break indicates that none of the series variables is stationary at its level value, However significant break dates have been identified as 1992 for the gross domestic product, 2001 for financial development and 2010 for the trade openness variable. The results also have shown that the variables, are stationary at first difference, with significant break date as 2011. Therefore, having found that, all the series variables, are stationary at their first difference values, the necessary condition for the test for cointegration has been fulfilled and it is conducted below using, the Gregory and Hansen (1996), Gregory and Hansen (1996) approach of cointegration.

Gregory and Hansen Cointegration and Interpretation of Results

This paper section presents the results for the cointegration test with the, presence of the structural breaks using Gregory and Hansen (1996) Gregory and Hansen (1996), approach.

Table 3:- Gregory \& Hansen cointegration Results with structural breaks.

\begin{tabular}{|c|c|c|c|c|}
\hline Model & Level & \begin{tabular}{l}
\multicolumn{1}{c}{ Level } \\
shift and \\
Trend
\end{tabular} & e. & $\begin{array}{l}\text { Regim } \\
\text { e Shift \& } \\
\text { Trend }\end{array}$ \\
\hline $\mathrm{ADF}$ & - & - & -4.86 & -5.28 \\
\hline statistic & $5.24 * *$ & $5.32 * *$ & & \\
\hline $\begin{array}{l}\text { Break } \\
\text { Date }\end{array}$ & 2010 & 1992 & 2010 & 1991 \\
\hline
\end{tabular}

Source: Computed by the Authors using stata 14.0 from the data obtained, from the bulletin of central Bank of Nigeria (2015).

Notes: ** indicates significance at level of 5 percent.
The cointegration test result, with single structural break, at unknown date test the null hypothesis for the test is that, there is, no cointegration as against the alternative hypothesis, that, there exist cointegarion. The Gregory and Hansen cointegartion approach has four model and cointegration exist in any of the models if the absolute value, of the $\mathrm{ADF}, \mathrm{Z} \alpha$ ad $\mathrm{Zt}$ are greater, than 1.5 or 10 per cent significance level. The results in Table 4 indicates that for the model that considers only break in level without trend it is significant at 5 percent level since the ADF statistic is significant with the break date in 2010 that coincides with the period when there is political uncertainty due to the illness of the president of Nigeria at that time. The model with the level shift and trend also indicates that the ADF statistic of -5.32 is also significant at 5 percent level of significant with the break date as 1992 which also can be explained as the break due the political crisis following the annulment of presidential election in 1992.

However, the results from Table 4 indicates that when the regime and regime with trend models are considered it indicates that there exist no cointegration among the variables as the ADF statistic is less than the 1,5 and 10 percent level value. Meaning that if the regime and regime trend are considered there is, no ling-run relationship among variables, in the model. Therefore, cointegration only exists when level and level and trend models are considered.

\section{Vector Error Correction Model and Interpretation of Results}

The cointegration existence among the variables, in the model as evidenced in Gregory and Hansen (1996) cointegraton approach has met the condition for the estimation of the vector error correction model to estimate the long-run, as well as short-run relationship among the variables as well as error correction term.

Estimating vector error correction model, requires that maximum lag to be used in estimating, the long-run and short-run relationship among the variables, in the model, using some information criteria. The information criteria suggest the use of 4 lags from both Akaike, Bayesian as well as the Hannan and quinn information criterion.

Table 4: Summary Results of the Optimum Lag Selection

\begin{tabular}{|c|c|c|c|c|c|}
\hline Criterion & $\mathbf{L}$ & $\mathbf{F}$ & AI & HQI & SB \\
\hline & $\mathbf{R}$ & PE & C & C & IC \\
\hline Optimum & 4 & 4 & 4 & 4 & 4 \\
\hline
\end{tabular}

Source: Computed by the author using Stata version 14 using data obtained, from the Statistical bulletin of Central Bank of Nigeria.

The maximum lag selected for testing the optimal lags required uses four lags and the results of the optimal lags selection in Table using the Likelihood Ratio (LR), final 
Predictor Error(FPE), Akaike Information Criterion (AIC), Hannan - Quin Information Criterion (HQIC) and Schwartz Bayesian Information Criterion (SBIC) suggest the use of 4 lags.

\section{Long Run Relationship and Interpretation of Results}

This subsection of the paper report the results of the normalized cointegrating regression equation and the interpretation of results.

Table 5: Summary of the Results of the Normalized Long run cointegration Results with Structural Breaks

Dependent Variable: Natural logarithm of Nominal Gross Domestic Product

\begin{tabular}{lll}
\hline Independent Variables & $\mathbf{1}$ & $\mathbf{2}$ \\
\hline Financial Development & 0.7381 & -0.1235 \\
& $3.2 * * *$ & $5.36 * * *$ \\
Trade Openness & 0.01433 & 0.1104 \\
& 0.19 & $8.88 * * *$ \\
Structural Break Dummy & & 6.5202 \\
(2011) & & $7.20 * * *$ \\
Adjustment Parameter & -0.004 & - \\
& & $0.047 * * *$ \\
R Squared & 52.95 & 54.67 \\
\hline
\end{tabular}

Source: Computed by the author using Stata 14 from data obtained, from Statistical Bulletin of Central bank of Nigeria (Various editions).

This section of the paper presents the results, of the normalized cointegration equation. That is, is the long-run relationship, between the dependent variable and independent variables (financial development and the trade openness). The result, from column 1 of Table 6 indicates that the financial development, has a significant and positive long-run relationship with economic growth, in the period of the study. Trade openness is indicate to have, a positive but none significant influence on the economic growth of Nigeria.

However, when the structural break dummy is considered, the coefficient of the financial development dropped from 0.7381 to 0.1235 and it indicates that, there exist a significant and negative relationship between the level of financial development and the economic growth. The trade openness contribution on the other hand turns out to be positive and significant. Meaning that trade contributes significantly, to the economic growth of Nigeria. Furthermore, the structural break dummy variable has a significant positive influence on the economic growth, at 1 percent significance level as the break date coincides with the period when the price of crude oil is on the increase thus more revenue for the government to finance its expenditure to promote economic growth.

The second argument that can be derived from the results in Table 6 is that including the structural breaks dummy helps in improving the significance and the reliability of the model. The trade openness variable turns out to be significant and the dummy variable is also significant at 1 percent significance level, Considering the importance of, adjustment in the vector error correction model, the model with c structural breaks in column-3 of Table 6 has shown that adjustment parameter improves from 0.004 to 0.047 and also significant at, 1 percent significance level, meaning that the speed of adjustment, from short-run disequilibrium is 4.7 percent to reach equilibrium annually. Furthermore, the inclusion of the break dummy has improved the coefficient of determination of the model as measured by R-square from 52.95 to 54.67. Therefore on the basis of this the model with structural breaks is used in drawing conclusion and policy implications for the paper.

\section{Diagnostic Checking on the stability of the model}

This section of the paper examines the adequacy of the model used in the study using the test for the normality of the residuals using the karlmigrov - smirnov test as well as testing the presence of serial correlation in the model and also checking for the stability of the residuals of the model using the grid circle from the eigen values of the model. The results of the test for normality of the residuals, indicates that the residuals are not normally distributed since the over all probability of the test of Jacque Bera for the v normality, of the residual, is less than 5 percent.

Table 6: Results of the Jacque Bera Test of the normality of the Residuals

\begin{tabular}{lccc}
\hline Equation & $\begin{array}{c}\text { Chi } \\
\text { square }\end{array}$ & $\begin{array}{c}\text { Degrees } \\
\text { of freedom }\end{array}$ & $\begin{array}{c}\text { Probability } \\
\text { of chi square }\end{array}$ \\
\hline Dlog GDP & 1.924 & 2 & 0.38216 \\
DFD & 12.182 & 2 & 0.0226 \\
Dopennees & 1.902 & 2 & 0.3863 \\
Ddummy & 3.105 & 2 & 0.2095 \\
All & 19.137 & 8 & 0.0141 \\
\hline
\end{tabular}

Also, as a robust check, the paper conduct tests, for presence of the serial correlation using the test of Langrange multiplier and the result is presented in the table below

Table7: Results of Langrange Multiplier test for serial correlation

\begin{tabular}{llcc}
\hline Lag & Chi square & Df & $\begin{array}{c}\text { Prob.chi } \\
\text { square }\end{array}$ \\
\hline 1 & 15.5155 & 16 & 0.45726 \\
2 & 20.1887 & 16 & 0.21184 \\
\hline
\end{tabular}

The LM test result for the presence of serial correlation shows that the null hypothesis of no serial correlation cannot be rejected as suggested by the probability values of the test statistic.

The stability condition of the vector error correction estimates was also found to be stable since the eigen values of the estimated residuals are all within the circle as shown in the fig. 


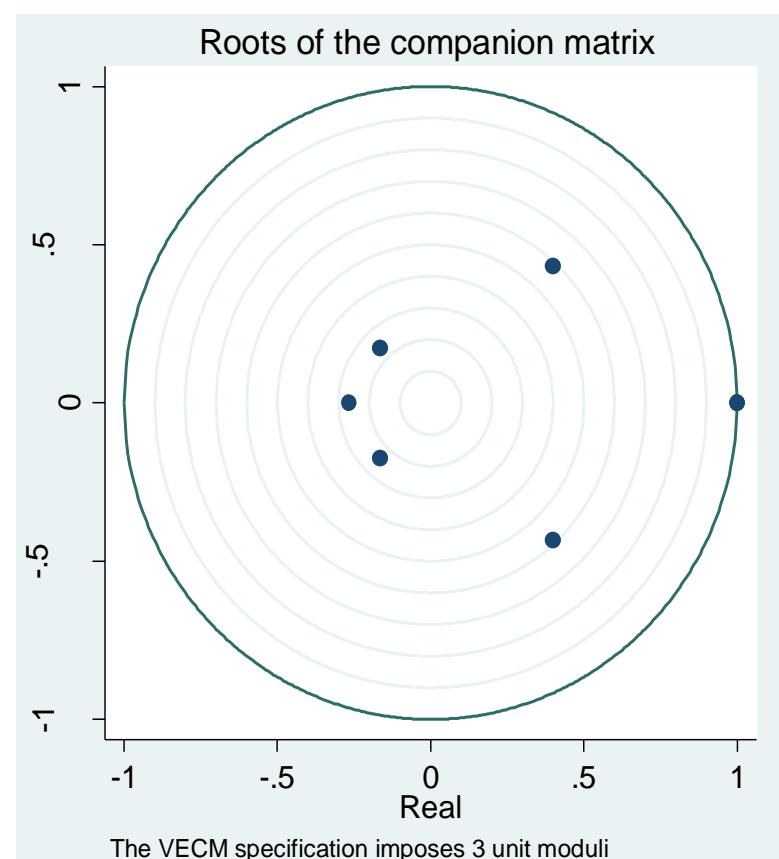

\section{DISCUSSIONS}

This investigates, the effect of the financial development on the economic growth of Nigeria while accounting for the presence of structural break. The study aims to investigate if financial development, has a significant effect on the economic growth in Nigeria.

The study finds out that on the relationship between the financial development and the economic growth in Nigeria that there exists a significant and negative effect of financial development on economic growth, in Nigeria which is, in line with the findings, of Naceur (2007) and Samargandi (2013) amongst other studies. However, the findings of the study contradicts the findings of Odeniran (2010), Udeaja (2010) and Zheng (2009) who finds a positive significant relationship between the financial development and the economic growth, suggested by, the theory guiding the study that the financial development, is expected to exert positive effect, on the economic growth.

The result of the study also indicates that taking into considerations the possibility of the presence of structural breaks in the vector error correction estimate helps in improving the significance and the reliability of the estimates of the model which implies that finding out the causes of structural breaks in time series datasets has a vital role in model estimations.

\section{CONCLUSION}

The result of the study indicates that the financial development, has a significant and negative long-run effect on the economic growth, in Nigeria. The result of the study has implications from both policy perspectives and conduct of future research.

The policy implications, for the study is that, financial sector reforms which aims at fostering financial sector and the economic growth in the long-run have adverse effect on economic growth by channeling resources away from the productive sectors of the economy such as agriculture and manufacturing to saving of money in financial institutions. Therefore, to foster economic growth in Nigeria, there is the need for government and private sectors to provide enabling institutions and environment for economic growth.

From the research perspective the study has shown that accounting for structural breaks improves the robustness of macroeconomic models. The study accounted for single break, future researches could be carried out considering multiple breaks and increasing the number of observations for a more robust result.

\section{REFERENCES}

1. Acaravci, A. (2010). "Structural breaks, electricity consumption and economic growth: evidence from Turkey." Journal for Economic Forecasting 2(2010): 140-154.

2. Akinlo, A. E. and T. Egbetunde (2010). "Financial development and economic growth: The experience of 10 sub-Saharan African countries revisited." The Review of Finance and Banking 2(1).

3. Balago, G. S. (2014). "Financial sector development and economic growth in Nigeria: An empirical investigation." International Journal of Finance and Accounting 3(4): 253-265.

4. BALIAMOUNE-LUTZ, M. (2013). "Financial Development and Income in African Countries." Contemporary Economic Policy 31(1): 163-175.

5. Bara, A., et al. (2016). "Financial innovation and economic growth in the SADC." African Journal of Science, Technology, Innovation and Development 8(56): 483-495.

6. Calderón, C., \& Liu, L. (2003). "The direction of causality between financial development and economic growth." Journal of development Economics 72(1): 321334.

7. Coser, L. A. (1956). The functions of social conflict 9.

8. Dabos, M. P. and E. R. Gantman (2010). "The fading link? a new empirical analysis of the relationship between financial development and economic growth."

9. Demetriades, P. O. and K. A. Hussein (1996). "Does financial development cause economic growth? Timeseries evidence from 16 countries." Journal of development Economics 51(2): 387-411.

10. Dickey, D. A. and W. A. Fuller (1979). "Distribution of the estimators for autoregressive time series with a unit root." Journal of the American statistical association 74(366a): 427-431.

11. Dilek, D., Ispir, M.S. \& hakan, Y. (2016). "Financial development and economic growth: Some theory and more evidence." Journal of policy Modelling 39(1): 290306.

12. Engle, R. F. and C. W. Granger (1987). "Co-integration and error correction: representation, estimation, and testing." Econometrica: Journal of the Econometric Society: 251-276.

13. Fang, X. and Y. Jiang (2014). "The promoting effect of financial development on economic growth: Evidence from China." Emerging Markets Finance and Trade 50(sup1): 34-50.

14. Garba, T., et al. (2016). "CENTRAL BANK OF NIGERIA." Economic and Financial Review 54(4).

15. Gregory, A. W. and B. E. Hansen (1996). "Practitioners corner: tests for cointegration in models with regime and trend shifts." Oxford bulletin of Economics and Statistics 58(3): 555-560.

16. Gregory, A. W. and B. E. Hansen (1996). "Residualbased tests for cointegration in models with regime 
shifts." Journal of econometrics 70(1): 99-126.

17. Huang, H. C. a. L., S. C. (2009). "Non-linear finance growth nexus." Economics of transition 17: 439-466.

18. Johansen, S. (1988). "Statistical analysis of cointegration vectors." Journal of economic dynamics and control 12(2-3): 231-254.

19. Kapingura, F. M. (2013). "Finance and economic growth nexus: Complementarity and substitutability between the banking sector and financial markets in Africa, using South Africa as a case1." Journal of Economics and International Finance 5(7): 273-286.

20. Kar, M. a. P., E. J. (2000). "Financial Development and Economic Growth in Turkey: Further Evidence on the Causality Issue." Economic Research Paper 00/27.

21. King, R. G., \& Levine, R. (1993). "Finance and growth: Schumpeter might be right." The quarterly journal of economics 108(3): 717-737.

22. Levine, R. ( 1997). "Financial development and economic growth: views and agenda." Journal of Economic Literature: 688-726.

23. Liang, H. J., \& Reichert, A. (2006). "The relationship between economic growth and banking sector development."

24. Lucas Jr, R. E. (1988). "On the mechanics of economic development." Journal of monetary economics 22(1): 342 .

25. Luntel, K. B. K., A. (1999). "A quantitative reassessment of finance-growth nexus: evidevence from multivariate VAR." Journal of Development Economics 60: 381-405.

26. Majd, S. A. (2017). "Financial Development and Income in African Countries. ." Contemporary Economic Policy 2(1): 163-175.

27. McKinnon, R. (1973). Money and capital in economic development. T. B. Institution. Washington D.C.

28. MEDHIN, H. A. and A. MEKONNEN (2019). "GREEN AND CLIMATE-RESILIENT TRANSFORMATION IN ETHIOPIA." The Oxford Handbook of the Ethiopian Economy.

29. Muhammad, S., and Lean, H. H. (2011). Does Financial Development Increase Energy Consumption? Role of Industrialization and Urbanization in Tunisia.

30. Naceur, S. B. a. G., S. (2007). "Stock markets, banks and economic growth: Empirical evidence from the MENAregion." Research in International Business and Finance 21: 297-315.

31. Odeniran, S. O. a. U., E. A. (2010). "Financial sector development and economic growth: Empirical evidence from Nigeria,." Central Bank of Nigeria Economic and Financial Review 48(3): 91-124.

32. Oluitan, R. (2010). "Bank credit and economic growth: The Nigerian experience." A Paper Presented at the AFE Conference in Greece 9th.

33. Phillips, P. C. B. a. P., P. (1988). " Testing for unit roots in a time series regression." Biometrica 75(2): 335-346.

34. Phillips, P. C. B. P., P. (1988). "Testing for unit roots in a time series regression." Biometrica 75(2): 335-346.

35. Qamarzumman, M. a. J. W. (2017). "Financial innovation and economic growth in Bangladesh." Financial Innovation 3(19): 1-24.

36. Robinson, J. (1952). The Rate of Interest and Other Essays. Macmillan. London:.

37. Rostow, W. W. (1960). The process of economic growth HB199(R65).

38. Samargandi, N., J. Fidrmuc, and Ghosh, S. (2013). Is the Relationship between Financial Development and Economic Growth Monotonic for Middle Income Countries? . Working Paper, Brunel University: 13-21.

39. Schumpeter, J. A. (1912). "The theory of economic development.".

40. Shaw, E. S. (1973). Financial deepening in economic development.
41. Stern, N. (1989). "The economics of development: a survey." The Economic Journal 99(397): 597-685.

42. Udeaja, O. (2010). "Financial sector development and economic growth: Empirical evidence from Nigeria." Central Bank of Nigeria Economic and Financial Review 43(3): 91-124.

43. Udeaja, O. a. (2010). "Financial sector development and economic growth: Empirical evidence from Nigeria." Central Bank of Nigeria Economic and Financial Review. 48(3): 91-124.

44. Zheng, C., and Yu, Y. (2009). "Financial Development and Economic Growth Based on the Panel Data (19942005) of All Provinces in China." 2009 International Conference on Business Intelligence and Financial Engineering: 790-793.

\section{AUTHORS BIOGRAPHY}

Sunday Elijah is a lecturer at federal university gusau, zamfara state, nigeria. he did his b.sc. economics at university of maiduguri; m.sc. economics at bayero university kano; a certified teacher of teachers registration council of nigeria; member, nigerian institute of management (chartered); member, institute of chartered economists of nigeria (icen); post graduate in education at usmanu danfodiyo university sokoto and currently a phd. scholar at department of economics, faculty of economics and management, universiti putra malaysia.

Namadina Hamza is a lecturer at federal university gusau, zamfara state, nigeria. he is a statistician and an economists. he obtained his diploma in statistics in kano state polytechnic, nigeria; b.sc. economics at usmanu danfodiyo university sokoto, nigeria; m.sc. economics at bayero university kano and currently a ph.d. scholar at usmanu danfodiyo university, sokoto, nigeria. ++he result of the study indicates that the financial development, has a significant and negative long-run effect on the economic growth, in nigeria. the result of the study has implications from both policy perspectives and conduct of future research. 